\title{
STUDI FENOMENOLOGI: KUALITAS HIDUP PASIEN HIPERTENSI SETELAH MENJALANI TERAPI BEKAM
}

\author{
Andika Syahputra ${ }^{1}$, Wan Nishfa Dewi ${ }^{3}$, Riri Novayelinda ${ }^{3}$ \\ ${ }^{1}$ PSIK Universitas Riau, ${ }^{2}$ PSIK Universitas Riau, ${ }^{3}$ PSIK Universitas Riau \\ Program Studi Ilmu Keperawatan Universitas Riau Jalan Pattimura No 9 Gedung G Pekanbaru Riau \\ Kode Pos 28131 Indonesia \\ Telepon 085364948485 email andikasyahputra930@gmail.com
}

\begin{abstract}
Abstrak
Pasien yang menderita hipertensi cenderung menyebutkan bahwa dirinya memiliki status kesehatan yang rendah dibandingkan dengan yang tidak hipertensi. Status kesehatan ini dapat mengindikasikan kualitas hidup yang tidak baik yang akan mempengaruhi fungsi fisik, psikologis, sosial, dan lingkungan. Penelitian ini bertujuan untuk mengeksplorasi lebih mendalam bagaimana kualitas hidup pasien hipertensi setelah menjalani terapi bekam di Rumah Sakit Ibu dan Anak Zainab. Data didapatkan dengan melakukan wawancara semi-struktur terhadap 3 orang partisipan yang diambil berdasarkan kriteria inklusi menggunakan tehnik purposive sampling. Hasil wawancara dianalisa dengan menggunakan metode Colaizzi. Hasil penelitian mengelompokkan empat tema yaitu: perubahan respon fisiologis: dapat menghilangkan rasa nyeri, menurunkan tekanan darah, meningkatkan kualitas tidur, perubahan respon psikologis: dapat memberikan perasaan positif seperti rasa senang, rasa nyaman serta mengandung nilai spiritual, perubahan dalam interaksi dan dukungan sosial: dapat meningkatkan interaksi sosial, memperoleh dukungan sosial, dan perubahan dalam aspek lingkungan: ekonomi yaitu harga pengobatan terjangkau dan fasilitas yang nyaman, aman, bersih, serta mudah diakses. Hasil dari penelitian ini merekomendasikan bagi pasien hipertensi agar tetap menjalani terapi bekam sebagai alternatif terapi komplementer.
\end{abstract}

Kata kunci: Hipertensi, Kualitas hidup, Terapi bekam

\begin{abstract}
Patients suffering from hypertension tend to mention that they have a low health status. This health status may indicate an unfavorable quality of life that will affect physical, psychological, social, and environmental functions. This research aims to explore how quality of life of hypertension patients after cupping therapy at Rumah Sakit Ibu dan Anak Zainab. Data were obtained by conducting semi-structured interviews with 3 participants who were selected based on the inclusion criteria using purposive sampling technique. Interview results were analyzed using the Colaizzi method. The results of the study grouped four themes, they are: physiological response change: can relieve pain, can lower blood pressure, improved sleep quality, change in psychological response: can provide positive feelings such as pleasure, comfort, and spiritual value, changes in interaction and social support: enhanced social interaction, obtain social support, and change in environmental aspects: economy affordable treatment prices and convenient, safe, and accessible facilities. The results of the research recommend for hypertension patients to keep therapy cupping as an alternative complementary therapy.
\end{abstract}

Keywords: Hypertension, Quality of life, Cupping therapy

\section{PENDAHULUAN}

Hipertensi atau penyakit tekanan darah tinggi merupakan suatu gangguan pada pembuluh darah dan penyakit kelainan jantung yang dtandai dengan peningkatan tekanan darah (Marliani \& Tantan, 2007). Hipertensi juga diartikan sebagai suatu keadaan dimana tekanan darah sistolik lebih dari $120 \mathrm{mmHg}$ dan tekanan darah diastolik lebih dari 80 mmHg (Muttaqin, 2009). 
Andika Syahputra ${ }^{1}$, Wan Nishfa Dewi ${ }^{3}$, Riri Novayelinda ${ }^{3}$,Studi Fenomenologi: Kualitas Hidup Pasien Hipertensi Setelah Menjalani Terapi Bekam

Ada dua tipe penyebab hipertensi, yaitu primer dan sekunder. Hipertensi yang tidak diketahui penyebabnya didefinisikan sebagai hipertensi primer. Hampir 90\% penderita hipertensi tergolong hipertensi primer, sedangkan $10 \%$-nya tergolong hipertensi sekunder.Adapun penyakit yang memicu timbulnya hipertensi sekunder diantaranya penyakit - penyakit pada ginjal, kelenjar adrenal, kelenjar tiroid, efek obat-obatan, dan karena kelainan pembuluh darah, serta pada kehamilan (Dalimartha, Purnama, Sutarina, Mahendra, \& Darmawan, 2008). Hipertensi juga dapat menimbulkan komplikasi yang berbahaya seperti infark miokardium, ensefalopati, stroke dan gagal ginjal (Ardiansyah, 2012).

Komplikasi yang ditimbulkan akibat hipertensi meningkat setiap tahunnya. Menurut World Health Organization (WHO) pada tahun 2013, menyebutkan bahwa di dunia terdapat 17 juta orang per tahun meninggal dunia akibat masalah pada kardiovaskuler dimana 9.4 juta orang diantaranya disebabkan oleh komplikasi dari hipertensi. Sedangkan di Indonesia hipertensi merupakan masalah kesehatan yang utama dengan prevalensi yang tinggi dengan berdasarkan hasil pengukuran pada umur $\geq 18$ tahun sebesar 25,8\%. (Riskesdas,2013).

Dinas Kesehatan Kota Pekanbaru (2016) menyebutkan bahwa hipertensi primer termasuk sepuluh besar kasus penyakit terbanyak di Pekanbaru yaitu menduduki urutan kedua terbesar setelah Infeksi Saluran Nafas Bagian Atas Akut lainnya (ISPA). Pada tahun 2013 angka penderita hipertensi tercatat sebanyak 20.005 kasus. Pada tahun 2014 berjumlah 20.601 kasus, jumlah ini meningkat pada tahun 2015 dengan jumlah 31.437 kasus, tetapi jumlah angka penderita hipertensi pada tahun 2016 sedikit mengalami penurunan dengan jumlah 31.396 kasus.

Dari beberapa data di atas mengindikasikan bahwa angka kejadian hipertensi masih tinggi. Oleh karena itu, tindakan pencegahan maupun penanganan sangat penting dilakukan untuk menghindari peningkatan penderita hipertensi. Salah satu bentuk penangan hipertensi yaitu berupa pengobatan hipertensi yang dapat dilakukan secara farmakologis dan non farmakologis (Sunaryo, Wijayanti, \& Kuhu, 2015).

Pengobatan farmakologis yang menggunakan obat-obatan tidak hanya memiliki efek yang menguntungkan, tetapi juga merugikan.Efek samping obat dapat menimbulkan reaksi yang tidak diinginkan bagi penderita seperti batuk, kelelahan, pusing, sering kencing, retensi cairan, disfungsi seksual, aritmia jantung, dan reaksi alergi (Kurniadi \& Nurrahmi 2015). Pada penggunaan obat lebih dari satu macam serta penggunaan obat jangka panjang akan meningkatkan risiko terjadinya Drug Related Problems. Drug Related Problems adalah segala macam keadaan yang tidak diinginkan yang dialami oleh pasien yang terlibat dan 
Jurnal Ners Indonesia, Vol. 9, No. 1, September 2019

disebabkan atau diduga melibatkan terapi pengobatan yang diberikan kepada pasien, yang secara nyata mau pun potensial dapat mempengaruhi keadaan pasien seperti ketidakpatuhan, interaksi obat, alergi terhadap obat yang diresepkan sehingga hal ini dapat memperburuk keadaan penyakit hipertensi itu sendiri (Sulistyarini, 2013).

Salah satu alternatif yang tepat untuk menurunkan tekanan darah tanpa ketergantungan obat dan efek samping adalah dengan pengobatan non farmakologis (Kowalski, 2010). Salah satu tren pengobatan non farmakologis untuk mengobati hipertensi saat ini yaitu dengan menggunakan bekam. Terapi bekam merupakan salah satu cara penyembuhan yang dianggap masyarakat Indonesia dapat membantu menurunkan tekanan darah pada penderita hipertensi (Kamaluddin, 2010). Bekam adalah terapi yang bertujuan membersihkan tubuh dari darahyang mengandung toksin dengan penyayatan tipis atau tusukan-tusukan kecil pada permukaan kulit. Bekam juga sering disebut sebagai terapi yang berfungsi untuk mengeluarkan darah kotor (Dalimartha et al., 2008).

Terapi bekam atau hijamah dianjurkan oleh Rasulullah Sallallahu'alaihi Wasallam. Refaat, Shemi, Ebid, Ashshi, dan Basalamah (2013), menggambarkan bekam dapat mencegah penyakit kardiovaskuler dengan menurunkan tekanan darah, menurunkan LDL (Low Density Lipoprotein) dan meningkatkan HDL (High-Density Lipoprotein). El-Sayed,
Al-quliti, dan Mahmoud (2014), membuktikan bahwa terapi bekam dapat membersihkan darah secara signifikan dari substansi yang menyebabkan penyakit seperti serum trigliserida, kolesterol total, LDLcholesterol, dan ferritin. Hal ini dapat membantu mengurangi permasalahan dan dapat menyembuhkan beberapa pnyakit seperti, hyperlipidemia, hipertensi, dan aterosklerosis. Hasil penelitian ini juga menginformasikan bahwa bekam dapat digunakan sebagai alternatif pengobatan. Hal ini karena terapi bekam mempunyai manfaat yang telah dibuktikan secara ilmiah dapat mengobati penyakit dengan cara membersihkan darah dan cairan interstisal dari subsanti penyebab penyakit (El Sayed, Mahmoud, \& Nabo, 2013 : Hasan, Ahmad, \& Ahmad, 2014).

Hipertensi terjadi karena adanya peningkatan sistem saraf simpatis yang mengakibatkan tekanan darah naik. Bekam dapat mengendalikan kadar hormon dan meningkatkan NitritOksida (NO) sehingga dapat menurunkan tekanan darah (Sharaf, 2012) dalam (Rofiq, 2016). Beberapa ciri yang dapat menggambarkan penyakit tekanan darah tinggi adalah sakit kepala, jantung berdebardebar, sakit ditengkuk, mudah lelah, penglihatan kabur dan perdarahan hidung (Ardiansyah, 2012). Kondisi ini pada akhirnya akan menimbulkan ketidaknyamanan dan mempengaruhi kualitas hidup penderita hipertensi. Hayws, Denny, Keenan, Croft, dan Greenlund (2008), menunjukkan 30\% 
Andika Syahputra ${ }^{1}$, Wan Nishfa Dewi ${ }^{3}$, Riri Novayelinda ${ }^{3}$,Studi Fenomenologi: Kualitas Hidup Pasien Hipertensi Setelah Menjalani Terapi Bekam

responden yang menderita hipertensi cenderung menyebutkan bahwa dirinya memiliki status kesehatan yang rendah dibandingkan dengan yang tidak hipertensi. Status kesehatan ini dapat mengindikasikan kualitas hidup yang tidak baik yang akan mempengaruhi fungsi fisik dan mental (Wang, Zau, \& He, 2009). Baune, Aljeesh dan Adrian (2005), semua dimensi dari kualitas hidup yang terdiridari psikologis, fisik, sosial dan lingkungan secara statistic memiliki hubungan yang sangat signifikan dengan hipertensi.

Kualitas hidup adalah persepsi seseorang tentang kondisi kesehatanya yang mempengaruhi kesehatan secara umum dalam pelaksanaan peran dan fungsi fisik serta keadaan tubuh (Raudatussalamah \& Fitr, 2012). Samiasih, dan Hartiti (2013), menemukan adanya peningkatan kualitas hidup sosial humaniora pasien migren setelah diberikan terapi bekam basah. Berdasarkan hasil wawancara yang peneliti lakukan dalam studi pendahuluan pada tanggal 9 juni 2017 dirumah kediaman pasien masing -masing dengan 2 pasien hipertensi yang menjalani terapi bekam ditemukan 2 pasien mengatakan peningkatan kualitas hidup ditandai dengan terdapat beberapa perubahan setelah menjalani terapi bekam. Diantaranya 2 orang pasien tersebut mengatakan sering mengeluhkan sakit kepala dan sakit di tengkuk, namun setelah menajalani terapi bekam pasien mengatakan ada perubahan yaitu sakit di kepala dan tengkuk berkurang, selain itu 2 orang pasien tersebut mengatakan setelah menjalani terapi bekam lebih nyaman dalam beraktivitas.

\section{METODE PENELITIAN}

Penelitian ini dilaksanakan di Rumah Sakit Ibu dan Anak Zainab yang dimulai dari bulan Februari sampai bulan Agustus 2017. Penelitian ini merupakan sebuah penelitian kualitatif dengan pendekatan fenomenologi. Metode penelitian kualitatif adalah penelitian yang pada umumnya menjelaskan dan memberikan pemahaman dan interpretasi tentang berbagai perilaku dan pengalaman manusia dalam berbagai bentuk (Afiyanti \& Rachmawati, 2014). Pendekatan fenomenologi ini memudahkan peneliti mengerti apa dan bagaimana suatu pengertian yang dikembangkan oleh subjek pada peristiwa didalam kehidupan sehari-hari. Tahapan metode fenomenologi yaitu memberikan pertanyaan dalam wawancara, melakukan analisa sesuai interaksi yang dilakukan, menulis makna dari pengalaman dalam bentuk narasi, menulis narasi sesuai dengan tujuan penelitian yang dilakukan (Putra, 2012).

Populasi dalam penelitian ini adalah pasien Hipertensi yang menjalani terapi bekam secara rutin di Rumah Sakit Ibu dan Anak Zainab sebanyak 182 orang dengan kriteria inklusi yaitu pasien hipertensi yang melakukan bekam secara rutin 1 kali dalam sebulan, usia 35-55 tahun, karena pada usia ini penderita hipertensi umumnya mengalami hipertensi sedang, yang efektif dilakukan pengobatan 
untuk mencegah komplikasi lebih lanjut, mampu berkomunikasi dengan baik dan berbahasa Indonesia dan bersedia ikut serta menjadi partisipan.

Jumlah partisipan dalam penelitian ini yaitu sebanyak 3 orang partisipan, karena jumlah partisipan yang terlibat dalam penelitian ini sesuai dengan design penelitian yang dilakukan, yaitu fenomenologi. Partisipan yang terlibat adalah orang yang mengalami penyakit hipertensi dan rutin melakukan terapi bekam sebagai alternatif pengobatan. Selain itu, jumlah partisipan dalam penelitian kualitatif, fenomenologi, bukan mewakili dari kelompok tertentu, sehingga informasi yang didapat tidak dapat digeneralisasikan. Pemilihan partisipan dilakukan dengan menggunakan teknik purposive sampling yaitu suatu teknik pengambilan sampel sumber data dengan pertimbangan tertentu.

\section{HASIL PENELITIAN}

\section{A. Gambaran karakteristik partisipan}

Semua partisipan dalam penelitian adalah pasien hipertensi yang menjalani terapi bekam di Rumah Sakit Ibu dan Anak Zainab Pekanbaru.Partisipan dalam penelitian ini berjumlah 3 orang yang dipilih menggunakan teknik Purposive sampling.Berikut adalah penjelasan karakteristik partisipan yang terlibat dalam penelitian ini.

\section{Partisipan 1:}

Partisipan adalah seorang laki laki yang berusia 37 tahun dan beragama
Islam.Partisipan sudah menjalani terapi bekam selama 1 tahun dan saat ini masih bekerja sebagai dosen di UIN SUSQA RIAU. Partisipan bersuku Jawa dan tinggal di Pekanbaru dengan pendidikan terakhir Magister Ekonomi.

\section{Partisipan 2:}

Partisipan adalah seorang perampuan yang berusia 53 tahun dan beragama Islam. Partisipan sudah menjalani terapi bekam selama 5 tahun dan saat ini masih bekerja sebagai guru SMP di Rumbai. Partisipan bersuku Minang dengan pendidikan terakhir Sarjana Pendidikan.

\section{Partisipan 3:}

Partisipan adalah seorang perampuan yang berusia 52 tahun dan beragama Islam.Partisipan sudah menjalani terapi bekam selama 3 tahun dan saat ini sudah tidak bekerja lagi.Partisipan bersuku Minang dengan pendidikan terakhir SMA.

\section{B. Hasil Analisa}

Analisa tematik pada penelitian ini dilakukan dengan cara menggunakan teori yang sudah ada yaitu teori tentang kualitas hidup menurut World Health Organization Quality of Life-BREF (WHOQOL-BREF). Teori WHO ini berhubungan dengan kesehatan umum yang meliputi kesehatan fisik, kesehatan psikologis, hubungan sosial, dan hubungan dengan lingkungan.Dalam menentukan hasil penelitian, peneliti mengacu kepada tema-tema yang sudah ada ditentukan oleh WHOQOL-BREF terkait kualitas hidup. Dari hasil analisa transkrip peneliti 
Andika Syahputra ${ }^{1}$, Wan Nishfa Dewi ${ }^{3}$, Riri Novayelinda ${ }^{3}$,Studi Fenomenologi: Kualitas Hidup Pasien Hipertensi Setelah Menjalani Terapi Bekam

mengelompokkan empat tema utamayaitu 1)

Perubahan respon fisiologis, 2) Perubahan respon psikologis, 3) Perubahan dalam interaksi dan dukungan sosial, 4) Perubahan dalam aspek lingkungan: ekonomi.

Adapun penjelasan setiap tema yang ditemukan adalah sebagai berikut:

\section{Perubahan respon fisiologis}

Hasil analisa transkrip interview yang dilakukan pada partisipan didapatkan bahwa adanya perubahan kualitas hidup pada pasien hipertensi yangditinjau dari aspek fisiologis, perubahan itu dapat dilihat dari ungkapanungkapan yang disampaikan oleh partisipan yang menyatakan bahwa setelah melakukan terapi bekam mereka merasakan nyeri yang berkurang, yang tadinya sering mengeluhkan sakit, pusing, sakit dibagian tengkuk dan kepala. Sekarang keluhan yang dirasakan sebelum melakukan terapi bekam tersebutsudah berkurang. Hal ini dapat dilihat dari pernyataan partisipan sebagai berikut:

"yang saya rasakan nyaman setelah bekam badan segar ee jarang pusingpusing..”, “...saya juga ini eeh kog pusingnya kurang biasanya sering nyeri ..."(P1-2)

“...setelah dicoba ia memang terasa lebih enak badan nyaman, itu setelah dibekam seperti tensi dah turun,badan ibu enaklah kepala pun tidak sakit"(P24)

"senanglah habis bekam ringan semua jadinya bagian kepala nilangsung kurang sakitnya, enak darah tu juga turun, apa aja semangat jadinya kita kerja, tidur biasanya susah sekarang sudah enakan..."(P3-7)
Selain dari pada itu, partisipan juga menyatakan bahwa dalam aspek fisiologis setelah dilakukan terapi bekam didapatkan adanya perubahan penurunan tekanan darah yang semulanya tekanan darahnya tinggi menjadi rendah, seorang partisipan juga mengatakan setiap kali beliau selesai melakukan terapi bekam beliau mengatakan apabila dilakukan pengecekan tekanan darah maka tekanan darahnya turun. Hal ini didapatkan dari pernyataan berikut :

“...rileks ee jarang pusing-pusing, saya juga ini eh kog pusingnya kuarang, biasanya sering nyeri, dulukan sering pusing pusing, migran, ia migranlah awalnya migran, ada tensi jugakan, tensinya juga berkurang setelah itu... (P1)

"...coba bekam itukan pengobatan ala nabi maka saya coba, setelah dicoba ia memang terasa lebih enak badan nyaman itu setelah dibekam seperti tensi dah turun, badan ibu enaklah kepala pun tidak sakit" (P2-4)

"senanglah habis bekam ringan semua jadinya bagian kepala ni langsung kurang sakitnya,enak, darah tuu juga turun, apa aja semangat jadinya kita kerja..." (P3-7)

Selain itu juga, partisipan menyatakan adanya perubahan dari aspek fisiologis setelah menjalani terapi bekam berupa adanya peningkatan kualitas tidur. Hal ini dapat dilihat dari ungkapan mereka yang mengatakan bahwa kualitas tidur menjadi lebih baik, yang semulanya susah tidur diakibatkan gejala dari hipertensi,namun setelah dilakukan terapi bekam partisipan merasakan tidurnya menjadi 
lebih nyaman. Seorang partisipanjuga mengatakan tidurnya lebih nyaman bahkan pada saat bekam beliau keseringan tertidur. Berikut pernyataan yang diungkapkan oleh partisipan:

“ ...rileks ee jarang pusing-pusing, saya juga ini eh kog pusingnya kuarang, biasanya sering nyeri, dulukan sering pusing pusing, migran, ia migranlah awalnya migran, ada tensi jugakan, tensinya juga berkurang setelah itu, pusingnya bekurangtidur juga enakan setelah bekam..."... kalau lagi bekam saya tidur diajak orang bekam itu ngomong saya tidur..."(P1-(1-3)

"senanglah habis bekam ringan semua jadinya bagian kepala ni langsung kurang sakitnya, enak, darah tuи juga turun, apa aja semangat jadinya kita kerja, tidur biasanya susah sekarang sudah enakan..."(P3-7)

\section{Perubahan respon psikologis}

Selain didapatkan adanya perubahan pada aspek fisiologis pada pasien hipertensi yang menjalani terapi bekam,dari hasil analisa transkrip interview peneliti juga mengelompokkan adanya perubahan kualitas hidup pasien hipertensi yang ditinjau dari aspek psikologis. Ungkapan-ungkapan yang disampaikan oleh partisipan terkait dengan perubahan kualitas hidup pasien yang menyatakan sepertiadanya perasaan positif: merasakan perasaan nyaman dan senang serta partisipan juga mengungkapkan dapat menerima kondisi penyakit yang dialami tanpa ada penolakan dan rasa kecewa. Pernyatan partisipan tentang perubahan kualitas hidup dapat dilihat dari pernyataan berikut: “...yang saya rasakan nyaman setelah bekam jarang pusing-pusing, saya juga ini eeh kog pusingnya kurang, biasanya sering nyeri dulukan sering pusingpusing migran, ia migranlah ada tensi jugakan, tensinya juga berkurang setelah itu...(P1-2)

“...Setelah dicoba ia memang terasa lebih enak badan nyaman, itu setelah dibekam seperti tensi dah turun..."(P25)

"...senanglah habis bekam ringan semua jadinya bagian kepala ni langsung kurang sakitnya, enak, darah tuu juga turun, apa aja semangat jadinya kita kerja, tidur biasanya susah sekarang sudah enakan..."...ibu juga merasa bahwa penyakit ini biasalah namanya juga sudah tuakan jadi ia diterimalah sambil dijalani pengobatannya (P3-7)

Selain dari pada itu, ada partisipan yang juga mengatakan adanya perasaan senang yang dirasakan pasien setelah melakukan terapi bekam.Ungkapan partisipan yang menyatakan perasaan senang dapat diwujudkan berupa tidak adanya kekhawatiran dalam mengikuti terapi bekam dan rasa nyaman karena penyakitnya sudah berkurang serta sakitnya juga hilang sesaat setelah dilakukan terapi bekam. Hal ini didapatkan melalui ungkapan berikut:

“...biasa saja awalnya geli tapi lamalama enak senanglah habis bekam ringan semua jadinya itu kalau lagi bekam saya tidur..."(P1-3)

"...ia biasa sebelum bekam sakit, tensinya juga ya tekanannya diatas normal tinggi, ibukan dah lama bekam hampir 5 tahunan lah jadi dengan bekam itu lebih enak 
Andika Syahputra ${ }^{1}$, Wan Nishfa Dewi ${ }^{3}$, Riri Novayelinda ${ }^{3}$,Studi Fenomenologi: Kualitas Hidup Pasien Hipertensi Setelah Menjalani Terapi Bekam

aja..."...pengalaman bekam pengen selalu dan nyaman..."(P2-5)

“...ibu enak aja tidak takut bahkan sakit itu juga hilang pada saat setelah bekam ituah membuat ibu nyamandengan bekam..."

...makanya ibu sekarang terasa berat ibu bekam biar enak ringan..." (P3-7)

Selain itu, partisipan yang lain juga mengatakan bahwa setelah melakukan terapi bekam ada terkandung nilai spiritual. Ungkapan partisipan yang menyatakan dengan melakukan terapi bekam merupakan salah satu ibadah dan merupakan sunnahRasulullah. Hal ini didapatkan melalui pernyataan berikut:

"bekam ini kan sunnah rosul dan juga bernilai ibadah"(P1-3)

“...biasanya kalau badan saya tidak enak berarti ada yang lebi ditubuh saya ntah kolesterol yang lebih untuk nngatasinya tulah bekam..."...inikan pengobatan ala nabi maka saya coba..." (P2-5)

\section{Perubahan dalam interaksi dan dukungan sosial}

Hasil analisa transkrip interview yang dilakukan pada partisipan, peneliti mengelompokkan adanya perubahan kualitas hidup pasien hipertensi yang dinilai dari aspek perubahan interakasi dan dukungan sosial, perubahan yang demikian itu dapat dilihat dari pendapat yang disampaikan oleh partisipan yang menyatakan bahwa mereka bisa menjalani aktifitas sosial yang tadinya sulit untuk dilakukan seperti mengikuti kegiatan majelis ta'lim. Berikut ungkapan yang disampaikan oleh partisipan adalah sebagai berikut:

“...ibu selalu ikut pengajian wirid majlis ta'lim gitu dekat dekat rumah, apalagi habis bekam ibu lebih bersemangat karena tenang rasanya kalau ikut pengajian gitu” (P3-7)

Salah satu partisipan juga mengatakan bahwa setelah dilakukan terapi bekam beliau dapat melakukan kegiatan yang berhubungan dengan pekerjaannya. Hal ini didapatkan dari pernyataan berikut:

“...bahkan kalau sudah sakit sekali saya cancel mengajar saya telpon mahasiswa saya bahwa saya tidak bisa mengajar. Namun setelah bekam ini saya merasa saya lebih enakan dan memang tidak pernah lagi saya pusing seperti dulu kalaupun ada tidak seberapa tidak sampai harus membatalkan mengajar kecuali ada keperluan lain yang tidak bisa ditunda gitu..." (P1-2)

Selain itu, partisipan juga mendapatkan perhatian yang positif dari orang sekitar dengan mngatakan bahwa apa yang saya lakukan ini merupakan hal yang baik. Hal ini dapat ditemukan melalui pernyataan berikut:

"disampaikan oleh teman bahwa ada bekam dirumah sakit zainab, diskusilah saya jelasnya kan sebelumnya saya juga pernah bekam dibekasi, tapi tidak rutin sekarang lah mungkin sudah hampir satu tahunanlah, setelah menjalani terapi bekam saya merasa ada perubahan dan teman-teman pun mendukung saya..."(P1-3)

"...penyakit hipertensi itu karena keturunan dari orang tua ibu, dia juga hipertensi dan juga karena usia ibu 
sudah tua jadi hipertensi, jadi ibu nya ibu suruh berbekam saja..." (P3-7)

\section{Perubahan dalam aspek lingkungan: ekonomi}

Hasil analisa transkrip interview pada aspek lingkungan peneliti mengelompokkan adanya kemudahan dalam segi ekonomi.Hal itu dapat dilihat dari ungkapan-ungkapan yang disampaikan oleh partisipan yang menyatakan bahwa setelah mereka mengikuti terapi bekam mereka tidak merasakan adanya peningkatan beban penggunaan biaya pengobatan dan mereka juga merasakan adanya kemudahan dalam mengakses fasilitas kesehatan serta fasilitas yang tersedia nyaman, aman, bersih dan partisipan juga bisa melakukan konsultasi dengan dokter. Berikut ungkapan yang disampaikan oleh partisipan.

"saya lebih nyaman di zainab tidak terlalu mahal sedang lah"(P1-3)

"tidak juga harganya tidak menjadi beban fikiran terjangkaulah dan inikan pengobatan ala nabi maka saya coba"(P2-5)

"tidak juga harganya tidak menjadi beban fikiran bisalah ibu, ibu juga senang bekam dizainab itu fasilitasnya nyaman aman dan bersih bisa konsultasi juga dengan dokter" (P3-8)

\section{PEMBAHASAN}

Penelitian tentang kualitas hidup pasien hipertensi setelah menjalani terapi bekam telah mengidentifikasi 4 (empat) tema yaitu: perubahan respon fisiologis, perubahan respon psikologis, perubahan dalam interaksi dan dukungan sosial, serta perubahan dalam aspek lingkungan: ekonomi.

A. Perubahan respon fisiologis

Hasil penelitian ini menunjukkan bahwa setelah dilakukan terapi bekam terhadap pasien hipertensi didapatkan adanya perubahan pada kualitas hidup yang ditinjau dari aspek fisiologis yaitu menghilangkan rasa nyeri. Hasil penelitian ini diperkuat dengan penelitian yang dilakukan oleh Ullah (2007), tentang investigasi efektifitas terapi bekam pada perawatan nyeri tulang kaki yang mengatakan bahwa terapi bekam dapat mengatasi gangguan pada darah, meringankan nyeri, relaksasi mental dan fisik. Ahmadi (2009), tentang The effectiveness of wetcupping for nonspesificl low back pain in Iran:

A Randomaized Cotrolled Trial dalam penelitannya mengatakan adanya penurunan nyeri setelah dilakukan terapi bekam.

Selain itu, peneliti juga menganalisa adanya perubahan yang dilihat dari aspek fisiologis yaitu dapat menurunkan tekanan darah pada pasien hipertensi setelah menjalani terapi bekam. Hasil penelitian ini didukung oleh Fera (2012), yang mengatakan bahwa terjadi penurunan tekanan darah rata-rata pada 20 responden hipertensi sebelum dan sesudah mendapatkan terapi komplementer bekam dengan nilai $\mathrm{p}$ value sistol: 0,000 dan $\mathrm{p}$ value diastol : 0,003 dimana $\mathrm{p}<0,05$ yang menununjukkan bahwa terapi bekam dapat menurunkan tekanan darah penderita hipertensi. 
Andika Syahputra ${ }^{1}$, Wan Nishfa Dewi ${ }^{3}$, Riri Novayelinda ${ }^{3}$,Studi Fenomenologi: Kualitas Hidup Pasien Hipertensi Setelah Menjalani Terapi Bekam

Pembekaman pada titik bekam, maka akan terjadi kerusakan mast cell dan lain-lain pada kulit, jaringan bawah kulit (sub kutis), fascia dan otot, akibat kerusakan ini akan dilepaskan beberapa mediator seperti serotonin, bradikinin, zat-zat ini menyebabkan terjadinya dilatasi kapiler dan arteriol serta flare reaction pada daerah yang dibekam, dilatasi kapiler juga dapat terjadi ditempat yang jauh dari tempat pembekaman, hal ini mengakibatkan terjadinya perbaikan mikrosirkulasi pembuluh darah. Akibatnya timbul efek relaksasi (pelemasan) otot-otot yang kaku serta akibat vasodilatasi umum akan menurunkan tekanan darah secara stabil (Umar, 2008).

Penelitian ini mengelompokkan adanya perubahan aspek fisiologis pasien hipertensi setelah mendapatkan terapi bekam berupa peningkatan kualitas tidur, yaitu kualitas tidur menjadi lebih baik. Penelitian yang dilakukan terkait dengan terapi komplementer yang lain yaitu berhubungan dengan kualitas tidur seperti yang dilakukan oleh Majid (2014), menemukan adanya perbedaan kualitas tidur sebelum dan sesudah pemberian terapi komplementer akkupresur. Perbedaan tersebut terlihat dari peningkatan respon kualitas tidur secara subyektif, pengurangan waktu yang diperlukan untuk memulai tidur, peningkatan lamanya waktu tidur, peningkatan efisiensi tidur, serta berkurangnya gangguan tidur pada siang hari. Perasaan nyaman tenang dan rileks merupakan pengaruh dari terapi komplementer (akkupresur), sehingga dapat meningkatkan kualitas tidur seseorang. Hal ini bisa dikaitkan dengan terapi komplementer yang sifatnya sama seperti yang dilakukan penelitian saat ini yaitu dengan menggunakan terapi bekam.

B. Perubahan respon psikologis

Hasil penelitian ini didapatkan bahwa setelah dilakukan terapi bekam terhadap pasien hipertensi juga didapatkan adanya perubahan pada kualitas hidup yang ditinjau dari aspek psikologis yaitu mereka merasakan perasaan nyaman. Hasil penelitian ini sejalan dengan penelitian terapi komplementer yang lain yang dilakukan Olnei (2005), dalam Arifin, Harmayetty dan Sriyono (2012), mengatakan bahwa terapi komplemter (back massage) yang merupakan salah satu jenis terapi komplementer yang sudah terbukti dapat memberikan efek relaksasi dan menurunkan tekanan darah pada penderita hipertensi, terapi yang diberikan memiliki efek penurunan tekanan darah melalui peningkatan vasodilatasi pembuluh darah dan mengurangi sekresi hormone stress, efek relaksasi melalui penurunan sekresi hormon ketokolamin akan berlanjut pada penurunan aktivitas saraf simpatis disertai penurunan tekanan darah. Rasa enak dan nyaman akan tercapai sehingga secara psikis memberikan dampak positif bagi pasien berupa rasa tentram, nyaman, rileks dan stress yang menurun (Valentine, 2008).

Selain memberikan efek psikologis berupa perasaan positif: rasa nyaman dan senang, peneliti juga menganalisa adanya 
terkandung nilai spiritual yang dirasakan partisipan setelah melakukan terapi bekam. Penelitian ini terbukti dengan adanya hadis Nabi Muhammad Sallallahu 'alaihi wasallam berbunyi "Kesembuhan itu terdapat pada tiga hal yaitu minum madu, sayatan alat bekam, dan kay (pembakaran) dengan api, dan sesungguhnya aku melarang ummat ku dari kay.” Sabda yang lain "Sungguh pengobatan yang paling utama yang kalian gunakan adalah bekam" (Hadis Bukhari) (Yasin, 2007).

C. Perubahan dalam interaksi dan dukungan sosial

Hasil analisa pada penelitian ini menunjukkan bahwa terdapat perubahan pada kualitas hidup yang ditinjau dari aspek interaksi dan dukungan sosial yaitu setelah melakukan terapi bekam mereka dapat merasakan perubahan bahwa mereka bisa menjalani aktivitas sosial yang tadinya sulit untuk mengikuti kegiatan seperti majelis ta'lim diakibatkan oleh gejala dari hipertensi salah satunya nyeri tengkuk dan kepala, sehingga sekarang sudah lebih leluasa dalam mengikuti rutinitas sosialnya tersebut.

Salah satu partisipan juga mengatakan bahwa setelah beliau menjalani terapi bekam beliau dapat melakukan kegiatan diluar yang berhubungan dengan pekerjaannya. Umar (2008), menyebutkan bahwa ketika seorang berbekam maka akan terjadi pelepasan zat neourokimia seperti endorphin yang bisa memberikan efek relaksasi dan mengurangi nyeri.
Hasil penelitian ini didukung oleh penelitian terapi komplementer yang lain yang dilakukan Kamaluddin (2010), menemukan adanya pengaruh terapi komplementer bekam terhadap penurunan tingkat nyeri, dan dapat meningkatkan hubungan sosial, efek yang ditimbulkan akibat nyeri sering mempengaruhi semua aspek kehidupan penderitanya, menimbulkan distress gangguan emosi dan mengganggu fungsi fisik dan sosial.

D. Perubahan dalam aspek lingkungan: ekonomi

Hasil penelitian mengungkapkan bahwa setelah partisipan mengikuti terapi bekam mereka tidak merasakan adanya peningkatan beban penggunaan biaya pengobatan dan mereka juga merasakan adanya kemudahan dalam mengakses fasilitas kesehatan yang ada. Hal ini sesuai dengan penelitian yang dilakukan Kristiono dan Wardani (2013), mengatakan bahwa pasien yang menjalani pengobatan terapi komplementer alternatif tidak memiliki masalah terhadap status ekonomi dikarenakan pengalaman dalam pengobatan alternatif tersebut.

\section{SIMPULAN}

Hasil penelitian ini dikelompokkan menjadi empat tema yang terdapat dalam kualitas hidup pasien hipertensi setelah menjalani terapi bekam yaitu: perubahan respon fisiologis, perubahan respon psikologis, perubahan dalam interaksi dan dukungan sosial, serta perubahan dalam aspek lingkungan. Beberapa perubahan yang dapat 
Andika Syahputra ${ }^{1}$, Wan Nishfa Dewi ${ }^{3}$, Riri Novayelinda ${ }^{3}$,Studi Fenomenologi: Kualitas Hidup Pasien Hipertensi Setelah Menjalani Terapi Bekam

dilihat dari kualitas hidup pasien hipertensi melalui aspek sebagai berikut:

1. Aspek fisiologis

Partisipan yang menderita hipertensi mengungkapkan setelah menjalani terapi bekam didapatkan peningkatan kualitas hidup melalui aspek fisiologis yaitu bekam dapat mengurangu rasa nyeri, menurunkan tekanan darah, dan dapat meningkatkan kualitas tidur.

2. Aspek psikologis

Hasil analisa penelitian yang dilihat dari aspek psikologis yaitu bekam dapat memberikan rasa nyaman, tentram, rileks dan mengandung nilai spiritual.

3. Aspek dalam interaksi dan dukungan sosial

Peneliti menganalisa bahwa partisipan yang menderita hipertensi pada penelitian inimengalami masalah di interaksi sosial dan pekerjaan,namun setelah mendapatkn terapi bekam ditemukan adanya perubahan yang lebih baik pada sisi interaksi dan dukungan sosial.

4. Aspek dalam lingkungan

Partisipan yang menderita hipertensi mengungkapkan setelah menjalani terapi bekam didapatkan perubahan lingkungan yang lebih baik ditinjau dari segi ekonomi harga pengobatan terjangkau dan kemudahan akses pengobatan yang didapatkan.

\section{SARAN}

a. Bagi perawat

Hasil penelitian ini diharapkan perawat dapat memahami tentang terapi alternatif komplementer bekam yang dapat meningkatkan kualitas hidup pasien hipertensi, peran lainnya adalah perawat mempunyai peranan seperti care provider, counselor, educator, dan advocator dalam pelaksanaan terapi alternatIf komplementer bekam.

b. Bagi pelayanan keperawatan

Bagi pelayanan keperawatan diharapkan dapat dijadikan rekomendasi dibidang keperawatan sehingga terapi alternatif komplementer bekam dapat dijadikan salah satu intervensi keperawatan yang komperhensif dan saling melengkapi dalam pemberian asuhan keperawatan.

c. Bagi peneliti selanjutnya

Bagi peneliti selanjutnya, hasil penelitian ini, diharapkan dapat menjadi salah satu informasi untuk membantu penelitian yang terkait dengan tema yang sama untuk penelitian selanjutnya.

\section{DAFTAR PUSTAKA}

Afiyanti, Y., \& Rahmawati, N. (2014). Metode penelitian kualitatif dalam riset keperawatan. Jakarta: PT. Raja Grafindo Persada.

Ahmadi, A., Schwebel, D., Saeb, M., Mohammadi, R. (2009). The effectiveness of wet- cupping for nonspecific low back pain in iran: a randomaized controlled trial. Jurnal of Complementary Therapies in Medicine, 17, 9-15.

Ardiansyah, M. (2012). Medikal bedah untuk mahasiswa. Yogyakarta: Diva Press. 
Arifin, R., Harmayetty, \& Sriyono. (2012). Perbedaan communication back massage dajn back massage dalam menurunkan tekanan darah pada klien dengan lansia dengan hipertensi. Surabaya: Universitas Airlangga.

Baune, B. T., Aljeesh, Y. I., \& Adrian, I. (2005). Predictors of quality of life among hypertensive patients with and without stroke. Journal of The Islamic University of Gaza (Natural Sciences Series) Vol, 13(2), P91-107.

Dalimartha, S., Purnama, B. T., Sutarina, N., Mahendra, B., \& darmawan, R. (2008). Care your self, hipertensi. Jakarta: Penebar Plus.

Dalimartha, S., Purnama, B. T., Sutarina, N., Mahendra, B., \& darmawan, R. (2008). Care your self, hipertensi. Jakarta: Penebar Plus.

Dinkes Kota Pekanbaru. (2016). Daftar sepuluh penyakit terbesar kota pekanbaru. Pekanbaru: Dinkes Kota Pekanbaru.

El Sayed, S. M., Al-quliti, A. S., Mahmoud, H. S., Baghdadi, H., Maria, R. A., Nabo, M. M. H., \& Hefny, A. (2014). Therapeutic benefits of Al-hijamah: in light of modern medicine and prophetic medicine. American Journal of Medical and Biological Research, 2(2), 46-71.

El Sayed, S. M., Mahmoud, H. S., \& Nabo, M. M. H. (2013). Medical and scientific bases of wet cupping therapy (Alhijamah): in light of modern medicine and prophetic medicine. Alternative \& Integrative Medicine, 1-16.

Ferra, (2012). Pengaruh terapi bekam terhadap tekanan darah pada pasien hipertensi di klinik bekam de besh center arrahmah dan rumah sakit sabbihisma kota padang. Padang: Jurnal Keperawatan Universitas Andalas. Hasan, I., Ahmad, T., \& Ahmad, S. (2014). Management of Hypertension by Wet Cupping Therapy (Al-Hijamah): A Case Study. International Journal of Pharmacology \& Toxicology, 4(1), 2427.

Hayes, D. K., Denny, C. H., Keenan, N. L., Croft, J. B., \& Greenlund, K. J. (2008). Health-related quality of life and hypertension status, awareness, treatment, and control: National Health and Nutrition Examination Survey, 2001-2004. Journal of hypertension, 26(4), 641-647.

Kowalski, R. E. (2010). Terapi hipertensi: program 8 minggu menurunkan tekanan darah tinggi dan mengurangi resiko serangan jantung dan stroke secara alami. Bandung: Qanita.

Kristiono, R. S., \& Wardani, Y. (2013). Faktor-faktor yang berhubngan dengan pola pencarian pengobatan ke pelayanan kesehatan alternatif pasien suspek tuberculosis di komunitas. Yogyakarta: Universitas Ahmad Dahlan Yogyakarta.

Kurniadi, H., \& Nurrahmi, U. (2015). Stop! diabetes hipertensi kolestrol tinggi jantung koroner memahami penyakit \& pencegahan deteksi awal penyakit \& akurat menu diet \& pola makan sehat \& jenis olah tubuh yang mendukung penyembuhan pola pengobatan tradisional dan herbal. Yogyakarta: Istana Media.

Majid, Y. A. (2014). Pengaruh akkupresur terhadap kualitas tidur lansia di balai perlindungan sosial tresna werdha ciparay. Bandung: Universitas Padjajaran.

Marliani, L., \& Tantan, S. (2007). 100 Questions \& Answers: Hipertensi. Jakarta: PT Elek Media Komputindo.

Muttaqin, A. (2009). Asuhan Keperawatan klien dengan gangguan sistem kardivaskular. Jakarta: Salemba Medika.

Putra. (2012). Metode penelitian kulaitatif pendidikan. Jakarta: PT. Raja Grafindo Persada.

Raudatussalamah \& Fitri, A.R. (2012). Psikologi kesehatan. Pekanbaru: Almujtahadah Press.

Refaat, B., El-Shemi, A. G., Ebid, A. A., Ashshi, A., \& BaSalamah, M. A. (2013). Islamic Wet Cupping and Risk Factors of Cardiovascular Diseases: Effects on Blood Pressure, Metabolic Profile and Serum Electrolytes in Healthy Young Adult Men. Alternative \& Integrative Medicine, 1-8. 
Andika Syahputra ${ }^{1}$, Wan Nishfa Dewi ${ }^{3}$, Riri Novayelinda ${ }^{3}$,Studi Fenomenologi: Kualitas Hidup Pasien Hipertensi Setelah Menjalani Terapi Bekam

Riskesdas. (2013). Badan penelitian dan pengembangan kesehatan kementrian kesehatan Republik Indonesia tahun 2013. Diperoleh tanggal 9 Maret 2017 dari http://www.depkes.go.id/resources/down load/general/Hasil\%20Riskesdas\%20201 3.pdf.

Rofiq, E. A. P. (2016). Study komparasi bekam basah dan kering terhadap penurunan tekanan darah pada klien hipertensi. Tugas Akhir. Universitas Muhammadiyah Ponorogo

Samiasih, H., \& Hartini, T. (2013). Bekam basah meningkatkan kualitas hidup humaniora pasien migren. Semarang: Universitas Muhammadiyah Semarang. Sulistyarini, I. (2013). Terapi relaksasi untuk menurunkan tekanan darah dan meningkatkan kualitas hidup penderita hipertensi. Jakarta: Universitas Islam Indonesia.

Sunaryo., Wijayanti, R., Kuhu, M. M., Sumedi, T., Widyanti, E. D., Sukrillah, U. A., Riyadi, S., \& Kuswati, A. (2015). Asuhan keperawatan gerontik. Yogyakarta: CV. Andi Offset.

Ullah, K., Yuonis, A., \& Wali, M . (2007). An investigation into the effect of cupping therapy as a treatment for anterior knee pain and its potential role in health promotion. The Internet Journal of Alternatif Medicine . 4 (1): 626-8.

Umar, W.A. 2008. Sembuh dengan satu titik. Solo : Al Qowam.

Valentino, R.J. (2008). Convergen regulation of locus coeruleus activity as an adaptive response to stres., European Journal of Pharmacology. Vol. 583, Hal. 194-203

Wang, R., Zhao, Y., He, X., Ma, X., Yan, X., Sun, Y., \& He, J. (2009). Impact of hypertension on health-related quality of life in a population-based study in Shanghai, China. Public health, 123(8), 534-539.

Yasin, S. A. (2007) Bekam sunnah nabi dan mukjizat medis. Cetakan VIII. Jakarta : Al-Qowam. 